\title{
Stubborn stones: breakages of a mechanical lithotripter by an exceptionally hard gallstone
}

\author{
Natalie Allen, ${ }^{1}$ Stephen Pettit, ${ }^{2}$ Abid $\mathrm{Ali}^{2}$
}

${ }^{1}$ Department of General Surgery, Blackpool Victoria Hospital, Blackpool, UK ${ }^{2}$ BWF Hospitals Trust, Blackpool, UK

\section{Correspondence to} Natalie Allen, na60@hotmail.co.uk

Accepted 8 April 2014

\section{DESCRIPTION}

Endoscopic retrograde cholangiopancreatography (ERCP) is the predominate method of removing common bile duct (CBD) calculi. ${ }^{1}$ The simplest and quickest way of removing large CBD calculi during ERCP is a mechanical lithotripter to crush the gallstone before removing the crushed fragments using balloon sweeping or a dormia extraction basket. We describe a case where the handle of the mechanical lithotripter broke off the metal sheath during crushing of an exceptionally hard $2 \mathrm{~cm}$ gallstone in an 83-year-old patient. This left the wire basket of the lithotripter firmly impacted around the gallstone in the CBD with the sheath of the lithotripter protruding from the patient's mouth (figure 1). Attempts to remove the lithotripter failed. The patient was transferred to the operating theatre and under general anaesthetic an upper midline laparotomy incision was made. The CBD was opened longitudinally allowing the impacted lithotripter basket and gallstone to be extracted (figure 2). The metal wires and sheath were divided near the entrapped basket (figure 3) using a wire cutter, allowing the sheath to be withdrawn from the patient's mouth. The CBD was closed using a continuous suture and cholecystectomy was performed. The patient was discharged 7 days later. Mechanical lithotriptors are designed so that the crushing wire basket preferentially breaks rather

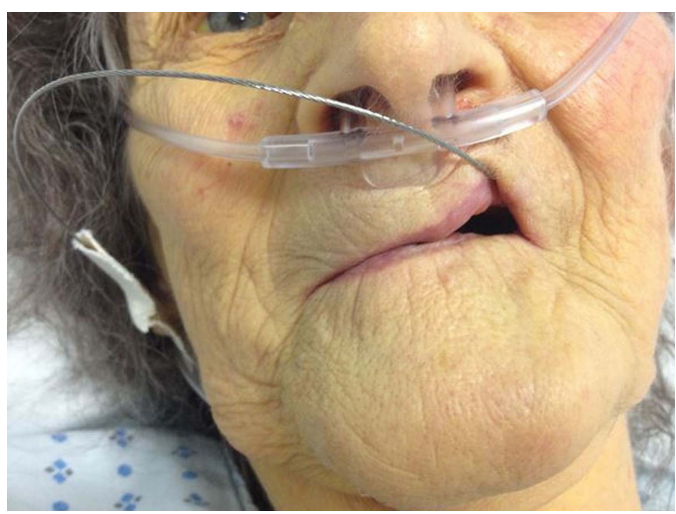

Figure 1 Photograph of the patient showing the metal sheath of the impacted lithotriptor protuding from her mouth.

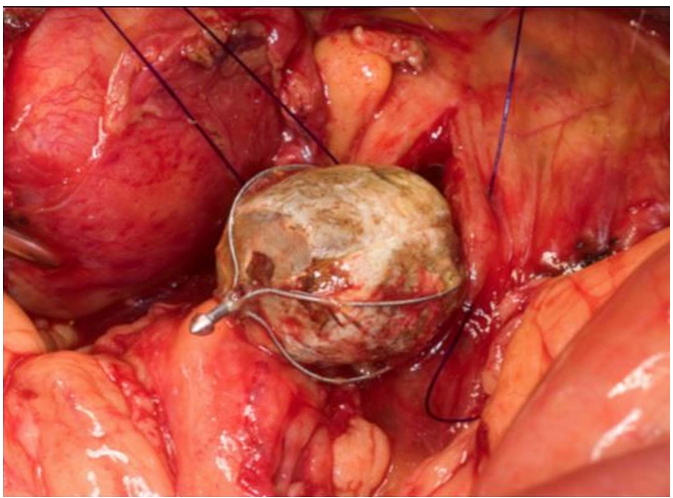

Figure 2 Gallstone and impacted lithotriptor basket being removed from the common bile duct at laparotomy.

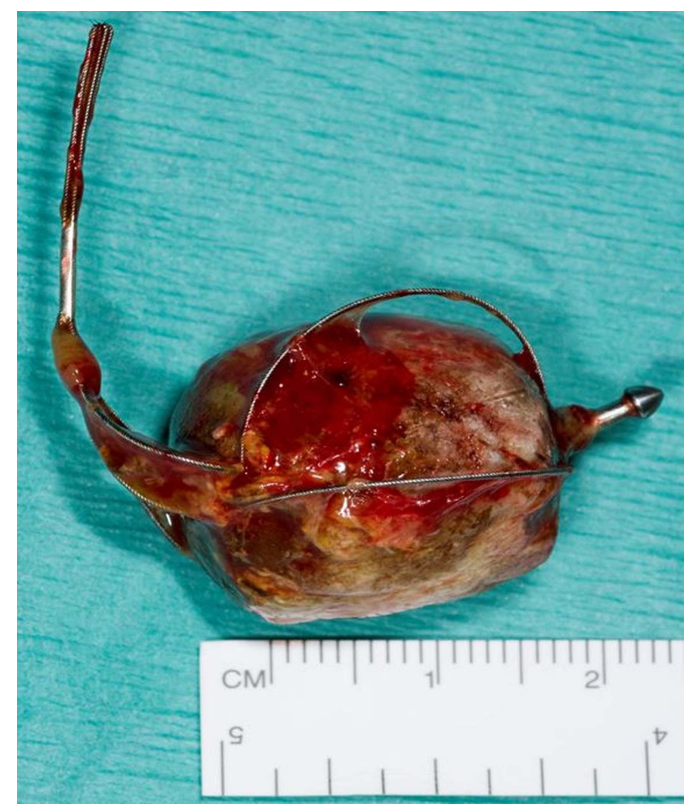

Figure 3 Gallstone with impacted lithotripter basket after division of the wires and sheath using a wire cutter.

than the crushing handle to avoid impaction. However, if the handle does break during lithotripsy of a hard gallstone, surgery as described here is the quickest way to resolve the situation. 


\section{Learning points}

- If the handle of a lithotripter breaks during stone crushing at endoscopic retrograde cholangiopancreatography the lithotripter cannot be removed from the patient and surgery is required.

- The common bile duct (CBD) can be safely closed without T tube drainage when it is thick-walled due to inflammation from CBD calculi and when a sphincterotomy has been performed.
Contributors SP was in charge of the patient's care; NA was involved in the patient's care, identified the case as a possible case report due to the lessons that could be learnt. AA performed a literature search; all the authors were involved in the writing up of the case and have viewed the final case report.

Competing interests None.

Patient consent Obtained.

Provenance and peer review Not commissioned; externally peer reviewed.

\section{REFERENCE}

1 Mullens JE, Laufer I. Endoscopic retrograde cholangiopancreatography in the management of pancreatic and biliary disease. Can J Surg 1976;19:405-9.

Copyright 2014 BMJ Publishing Group. All rights reserved. For permission to reuse any of this content visit http://group.bmj.com/group/rights-licensing/permissions.

BMJ Case Report Fellows may re-use this article for personal use and teaching without any further permission.

Become a Fellow of BMJ Case Reports today and you can:

- Submit as many cases as you like

- Enjoy fast sympathetic peer review and rapid publication of accepted articles

- Access all the published articles

- Re-use any of the published material for personal use and teaching without further permission

For information on Institutional Fellowships contact consortiasales@bmjgroup.com

Visit casereports.bmj.com for more articles like this and to become a Fellow 